\title{
Article
}

\section{The Ambiguous Functions of the Precursors That Enable Nonclassical Modes of Olanzapine Nucleation and Growth}

\author{
Monika Warzecha $^{1}\left(\mathbb{D}\right.$, Alastair J. Florence $^{1}$ and Peter G. Vekilov $^{2,3, *}$ \\ 1 EPSRC CMAC Future Manufacturing Research Hub, Technology and Innovation Centre, c/o Strathclyde \\ Institute of Pharmacy and Biomedical Sciences, 99 George Street, Glasgow G1 1RD, UK; \\ monika.warzecha@strath.ac.uk (M.W.); alastair.florence@strath.ac.uk (A.J.F.) \\ 2 William A. Brookshire Department of Chemical and Biomolecular Engineering, University of Houston, \\ 4726 Calhoun Road, Houston, TX 77204-4004, USA \\ 3 Department of Chemistry, University of Houston, 3585 Cullen Blvd., Houston, TX 77204-5003, USA \\ * Correspondence: vekilov@uh.edu
}

check for updates

Citation: Warzecha, M.; Florence, A.J.; Vekilov, P.G. The Ambiguous Functions of the Precursors That Enable Nonclassical Modes of Olanzapine Nucleation and Growth. Crystals 2021, 11, 738. https:// doi.org/10.3390/cryst11070738

Academic Editors: José Gavira,

Fajun Zhang, Geun Woo Lee and Dirk Zahn

Received: 24 May 2021

Accepted: 10 June 2021

Published: 26 June 2021

Publisher's Note: MDPI stays neutral with regard to jurisdictional claims in published maps and institutional affiliations.

Copyright: (c) 2021 by the authors. Licensee MDPI, Basel, Switzerland. This article is an open access article distributed under the terms and conditions of the Creative Commons Attribution (CC BY) license (https:// creativecommons.org/licenses/by/ $4.0 /)$.

\begin{abstract}
One of the most consequential assumptions of the classical theories of crystal nucleation and growth is the Szilard postulate, which states that molecules from a supersaturated phase join a nucleus or a growing crystal individually. In the last 20 years, observations in complex biological, geological, and engineered environments have brought to light violations of the Szilard rule, whereby molecules assemble into ordered or disordered precursors that then host and promote nucleation or contribute to fast crystal growth. Nonclassical crystallization has risen to a default mode presumed to operate in the majority of the inspected crystallizing systems. In some cases, the existence of precursors in the growth media is admitted as proof for their role in nucleation and growth. With the example of olanzapine, a marketed drug for schizophrenia and bipolar disorder, we demonstrate that molecular assemblies in the solution selectively participate in crystal nucleation and growth. In aqueous and organic solutions, olanzapine assembles into both mesoscopic solute-rich clusters and dimers. The clusters facilitate nucleation of crystals and crystal form transformations. During growth, however, the clusters land on the crystal surface and transform into defects, but do not support step growth. The dimers are present at low concentrations in the supersaturated solution, yet the crystals grow by the association of dimers, and not of the majority monomers. The observations with olanzapine emphasize that detailed studies of the crystal and solution structures and the dynamics of molecular association may empower classical and nonclassical models that advance the understanding of natural crystallization, and support the design and manufacture of promising functional materials.
\end{abstract}

Keywords: organic crystallization; crystal symmetry

\section{Introduction}

The formation of crystal nuclei in a supersaturated "old" phase overcomes a free energy barrier due to the formation of a new surface [1]. A solution supersaturated with respect to a crystal overcomes the nucleation barrier via fluctuations that bring the local concentration and structure close to those of the incipient phase [1]. These basic views on nucleation, complemented by a later kinetic model, constituted the "classical" nucleation theory (CNT) [2,3]. Perhaps the most sequential assumption of the classical approaches is the "Szilard postulate" [4], according to which crystals nucleate by association of single solute molecules [5]. In the last two decades, elaborate experiments have gathered significant discrepancies with the nucleation behavior predicted by classical theory [6-9]. Many of the deviant features present violations of the Szilard rule, and involve mesoscopic crystallization precursors, ordered or disordered, which assemble in the solution independently of crystallization and may host and facilitate nucleation [6,9-12]. 
Regarding the growth of the nucleated crystals, vigorous debate was waged on whether the crystals grow by association of monomers [13] or the alignment of preformed units $[14,15]$. Supported by analytical models [16,17] and careful experimentation [18], the molecular viewpoint ascended to classical status. Recent observations have, as in the case of nucleation, illuminated cases of non-classical crystal growth employing liquid, amorphous, and crystalline precursors [9,19-23] that are similar to those that host nucleation and embody another violation of the Szilard rule.

Here we examine the roles of two structures extant in olanzapine (OZPN) solutions, mesoscopic solute-rich clusters and molecular dimers, in the nucleation, crystal form transformations, and growth of OZPN crystals (Figure 1). OZPN is an antipsychotic drug [24], which precipitates in more than 60 individual crystal forms, not including salts and co-crystals [25]. Different solid-state forms have different crystallization free energies and, consequently, different thermodynamic stabilities [26]. The crystal form profoundly impacts the applications that rely on crystalline materials and their associated properties [27,28]. As the crystal structure and composition dictate the solubility and bioavailability of the drug, polymorphic transformations are responsible for a wide range of engineering difficulties in the production of pharmaceuticals [29,30]. The mechanism of transition between solid forms is among the major unsolved problems of modern materials science [31,32]. To partially fill this knowledge gap, we demonstrate that the OZPN-rich mesoscopic clusters facilitate the nucleation of a crystal hydrate, OZPN DD, during its transformation from the anhydrous OZPN I. We then examine the role of the clusters in crystal growth and, surprisingly, discover that the clusters integrate in the crystals as foreign bodies and do not contribute to growth, either as preformed building blocks. nor as a source of solute supply as they decay. In contrast to the clusters, the OZPN dimers are essential for growth: we show that the crystals grow exclusively by incorporation of solute dimers, the simplest preformed units, a growth mode which has been inferred from crystal and solution structures, but has not been experimentally observed [33,34]. Spectroscopic characterization exposes the olanzapine dimers as a minority solution component. To close the loop from clusters to dimers and back, we find that that transient solute dimers are likely essential building blocks of the clusters. In this way, the dimers not only underlie the growth of crystals, but are also a precondition for the nucleation precursors.
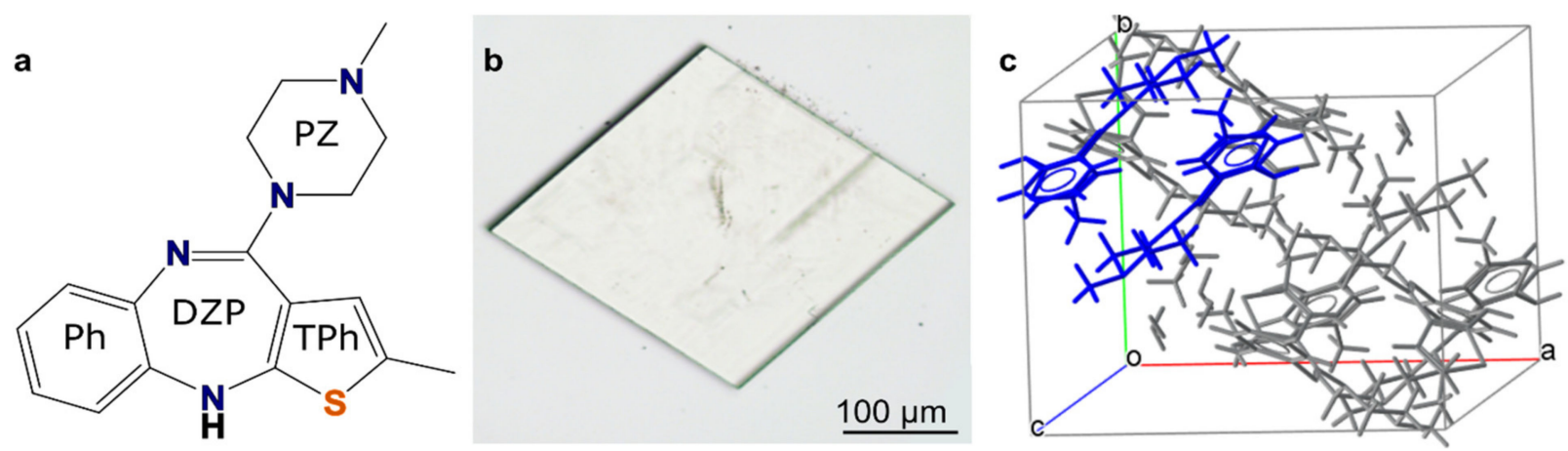

Figure 1. OZPN and its crystals. (a) The OZPN molecule: Ph, benzene ring; DZP, diazepine ring; TPh, thiophene ring; PZ, piperazine ring. (b) Optical micrograph of an OZPN crystal; the (002) face faces upwards. (c) The crystal structure of the dihydrate ethanoate mixed solvate 2OZPN.EtOH $2 \mathrm{H}_{2} \mathrm{O}$ in space group P21/c (Cambridge Structural Database REFCODE WEXQEW [35]). One centrosymmetric OZPN SC $\mathrm{O}_{0}$ dimer is highlighted in blue.

\section{Mesoscopic OZPN-Rich Clusters and Their Role in Nucleation of New Crystal Forms}

Classical theories envision two pathways by which a crystal polymorph may transform into another, more stable structure [31]. In enantiotropic transitions, the molecules in the crystal lattice rearrange to acquire a new more stable symmetry, whereas in monotropic transformations the original crystal dissolves and the new structure nucleates in the so- 
lution [36]. The enantiotropic pathway is more likely in crystals of isotropic molecules or particles, interacting with a "soft" potential, in which the attractive minima are flat, broad, and conducive of molecular motion [37]. For molecular crystals, in which the attractive forces are reasonably strong, short-ranged, and anisotropic, a more common option is dissolution of the metastable polymorph, along with crystallization of a more stable, less soluble, form.

AFM observations reveal that the transition between a non-solvated polymorph (OZPN I) [24] and two dihydrates (OZPN DD and DB) follows a mechanism distinct from these two pathways [38]. The OZPN transformation engages an intermediate, liquid-like phase, that deposits on $\{100\}$ faces of OZPN I (Figure 2a) and assists the nucleation of OZPN DD (Figure 2c,d) [38]. Complementary experiments reveal that, when dispersed into the solution bulk by stirring, the liquid clusters transform to an another metastable dihydrate polymorph, OZPN DB [38]. Furthermore, computational modeling established that the (100) surface of OZPN I templates the nucleation of dihydrate D [38]. The reasons why the liquid clusters support fast crystal nucleation are largely elusive. Numerous investigations that document the role of liquid and amorphous mesoscopic precursors in the nucleation of various materials have stopped short of providing detailed mechanistic explanation [5,8]. Analytical models predict controlling roles for the elevated solute concentration in the clusters and the lower surface free energy of the interface between the nucleus and the cluster phase, which have not been tested in critical experiments [39-41].
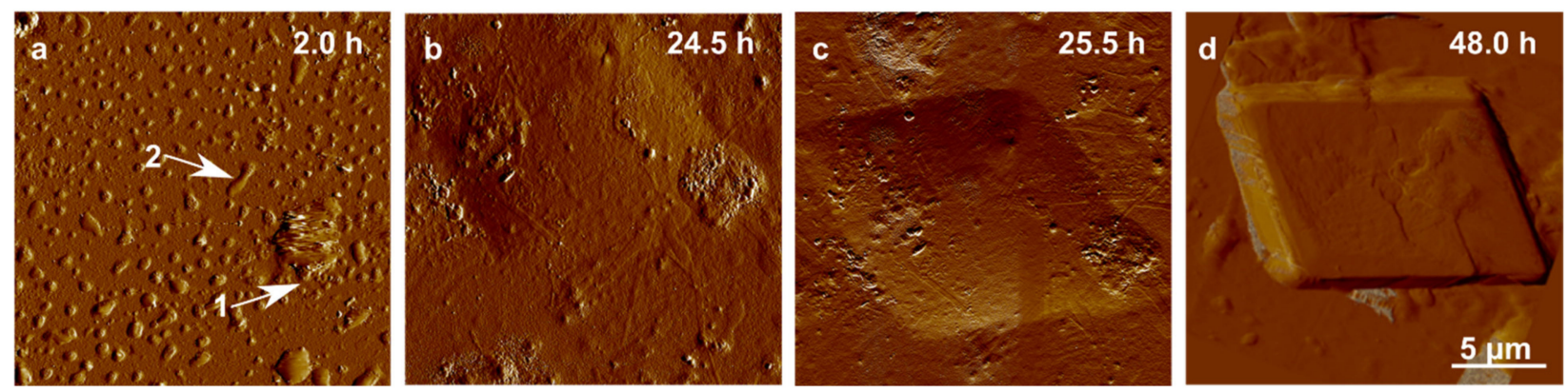

Figure 2. Mesoscopic OZPN-rich clusters on the surface of an OZPN I crystal host the nucleation of a new crystal forms, OZPN DD. AFM monitoring of the cluster evolution. (a) Clusters on a (100) face $2 \mathrm{~h}$ after introduction to solution. Arrows indicate cluster coalescence, evidence for the liquid composition of the clusters. $(\mathbf{b}, \mathbf{c})$ Further coalescence of clusters and emergence of facets indicate the nucleation and growth of an underlying crystal. (d) A fully developed OZPN DD crystal.

Nucleation of OZPN DD and OZPN DB from the dense liquid droplets challenges the assumptions of the monotropic pathway, according to which nuclei of the new polymorph emerge in the solution by ordered assembly of solute molecules, as proposed by classical nucleation theory [16,42-44]. By contrast, the observed process follows the two-step nucleation mechanism, according to which crystals nucleate within dense liquid precursors [10,45-49]. This mechanism has been observed with protein [10,11,45,49-55], colloid [56-58], inorganic [59-61], and organic [46,62,63] molecules. Macroscopic dense liquid stable with respect to the solution and appearing after the liquid-liquid phase separation (LLPS), has been observed with organic molecules [64] Cluster growth by merging with other clusters (Figure 2a-c) [38], rather than by addition of solute molecules from the solution, however, suggests they do not represent an 'oiling out' phase.

\section{The Mechanism of Formation of the Mesoscopic OZPN-Rich Prenucleation Phase}

To understand the puzzling leck of growth by association of solute monomers of mesoscopic OZPN-rich clusters, we monitor the properties of the cluster population and its evolution and deduce the cluster formation mechanism. We draw an analogy to the protein-rich clusters of similar size, which assemble owing to the dynamics of formation and decay of transient dimers [65]. We examine the cluster population with oblique illumination microscopy (OIM). This method relies on light scattered at wave vectors of 
order $\mu \mathrm{m}^{-1}$ and probe lengthscales in the range $10 \mathrm{~nm}-10 \mathrm{~m}$. The Rayleigh law, according to which the scattered intensity scales as the sixth power of the scatterers' sizes, makes this technique particularly well suited to study the mesoscopic clusters, which are $50-100 \mathrm{~nm}$ large, but are present at a very low concentration. A green laser $(532 \mathrm{~nm})$ illuminates a $500 \mu \mathrm{m}$ solution layer at an oblique angle such that the incident beam avoids the lens of a microscope positioned above the sample (Figure 3a) [66,67]. The light scattered by the solution inhomogeneities is seen as dark speckles in the negative image (Figure $3 b, c)$; if the scatterers are smaller than the diffraction limit, ca. $200 \mathrm{~nm}$, the speckle size accounts for the deviation of the cluster position from the microscope focal plane.
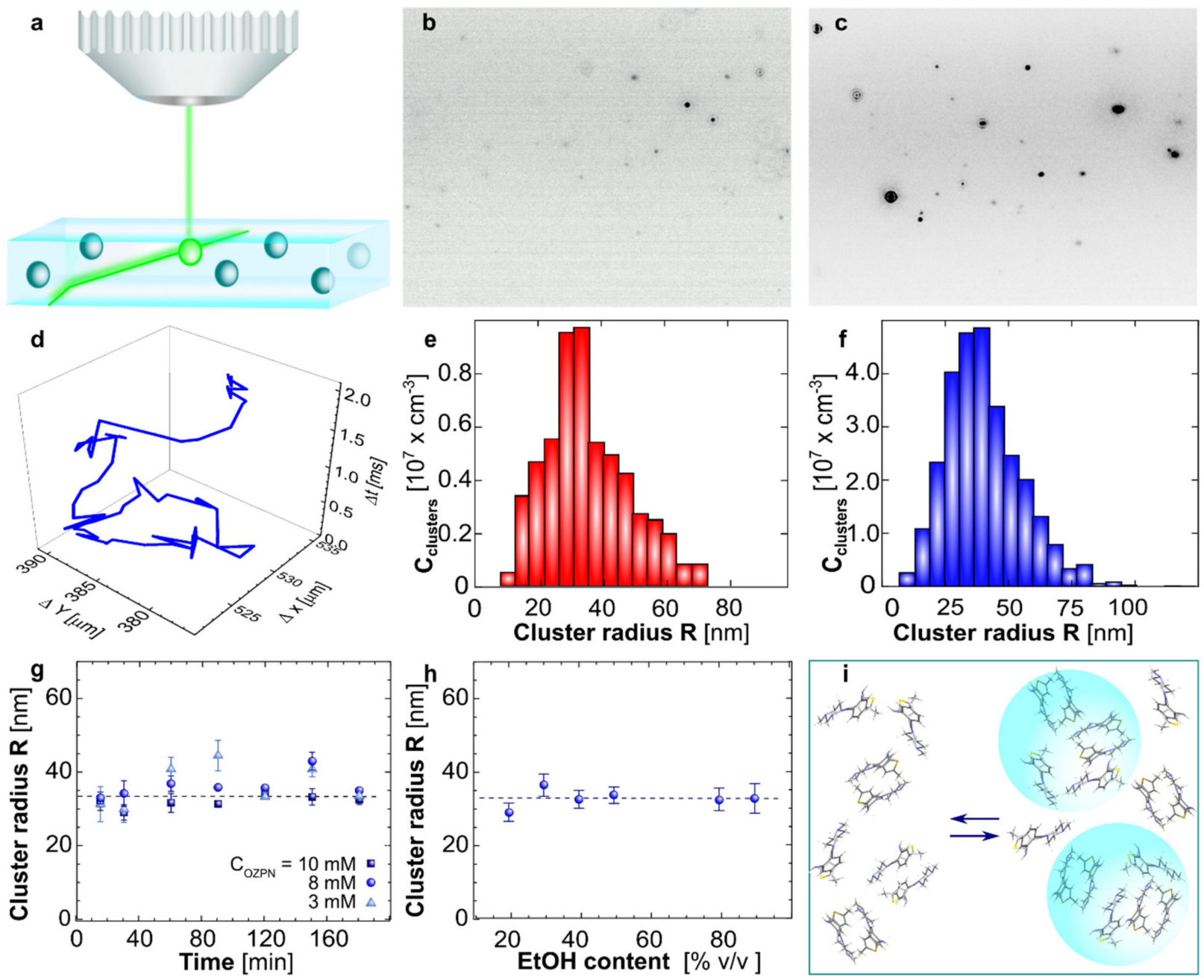

Figure 3. The mesoscopic OZPN rich clusters. (a) Schematic of oblique illumination microscopy (OIM). (b,c) Typical images, shown as negatives, in which the clusters appear as dark speckles, of OZPN-rich clusters in undersaturated OZPN solutions in $\mathrm{H}_{2} \mathrm{O}$, in (b) and in $80 / 20(v / v) \mathrm{EtOH} / \mathrm{H}_{2} \mathrm{O}$, in (c) The observed volumes are $120 \times 80 \times 5 \mu \mathrm{m}^{3}(\mathrm{~L} \times \mathrm{W} \times \mathrm{H})$. (d) The trajectory of a cluster in the plane of the image. (e,f) Distributions of cluster sizes obtained from five OIM movies recorded at distinct solution locations in undersaturated OZPN solutions in $\mathrm{H}_{2} \mathrm{O}$, in $(\mathbf{e})$ and in $80 / 20(v / v) \mathrm{EtOH} / \mathrm{H}_{2} \mathrm{O}$, in $(\mathbf{f}, \mathbf{g})$ The time evolutions of the average cluster radius $R$ in OZPN solutions with three concentrations in 80/20 ( $v / v)$ EtOH $/ \mathrm{H}_{2} \mathrm{O}$ solutions. (h) The average cluster radius $R$ in $\mathrm{EtOH} / \mathrm{H}_{2} \mathrm{O}$ solvents of different composition. (i) Schematic of formation of mesoscopic OZPN-rich clusters (highlighted in blue spheres) owing to the accumulation of transient dimers.

To avoid interference from nucleating crystals, we tested undersaturated solutions of OZPN. They are expected to be homogeneous at all lengthscales, including the molecular. Surprisingly, OIM observations revealed the presence of randomly diffusing particles (Figure 3b,c). To test if the units are crystals, we supplemented the OIM setup (Figure 3a) with a polarizer at the optical window of the cuvette and an analyzer in front of the objective 
lens. If the two polarizers are crossed, crystals, which rotate the plane of light polarization, would produce bright speckles. Our tests revealed that the field of view was completely dark, proving that the speckles seen without the polarizer (Figure $3 b, c$ ) are disordered. We recorded the Brownian trajectory of each cluster in the image plane (Figure 3d) and calculated the correlation between the mean squared displacement $\left\langle\Delta x^{2}\right\rangle$ and the lag time $\Delta t$. We used the diffusion coefficient $\mathrm{D}$ of individual clusters calculated from the slope of the $\left\langle\Delta x^{2}\right\rangle(t)$ correlation [68] and the Stokes-Einstein relation, $R=k_{B} T / 6 \pi \eta D$ to obtain the average cluster radius of ca. $35 \mathrm{~nm}$ (Figure $3 \mathrm{e}, \mathrm{f}$ ). This size is similar to the prenucleation phase observed on (100) surfaces OZPN crystals in aqueous solutions (Figure 2). The coalescence of two or more clusters (Figure $2 b, c$ ) implies that the clusters are liquid.

Solution concentration does not affect the cluster radius, and the size is steady in time for up to three hours (Figure 3g). This behavior is opposite to the evolution of a newly formed phase in which the domain size grows in time [69]. This size is much greater than estimated from colloid particles condensation models [70] that are often applied to aggregation in solution [71-78]. As the cluster population contains a minor fraction of the dissolved OZPN, the effect on initial concentration is minimal. The concentration of the solution in contact with the clusters is close to the initial 3, 8 , or $10 \mathrm{mM}$. This observation is beyond the reported behaviors of micelles, which equilibrate with solutions of constant critical micelle concentration (CMC). Thus, the OZPN clusters are not micelles.

Instead, these unique properties are typical of the mesoscopic solute-rich clusters, found in solutions of many proteins at varying conditions [19,52,65,79-81]. Similar to OZPN prenucleation phase, the protein cluster size is steady and independent of the parameters that dictate the solution thermodynamics, such as $\mathrm{pH}$, ionic strength, and protein concentration $[66,79,80,82]$. According to recent models the mesoscopic clusters form due to accumulation of transient dimers (Figure $3 i)[55,65,83]$. The propensity of OZPN to dimerize is evinced form the prevalence of dimers in the known crystallographic structures of this compound $[25,84]$. Importantly, the dimers that support cluster formation should only exist for a limited lifetime $[65,83,85,86]$ and may be distinct form the crystallographic units. In the clusters, the transient dimers co-exist with monomers $[87,88]$. This kinetic model accounts for the conversion of monomers to transient dimers, the diffusion of monomers to fill the void created by this conversion, and the outflow and decay of the transient dimers $[65,86,89]$. The cluster size appears as a square root of the product of the diffusivity of the dimers and their lifetime and is, hence, independent of the solute concentration and steady in time $[65,86,89]$. The mesoscopic clusters of OZPN appear to agree with the predictions of this model remarkably well. In further compliance with the transient dimer model to the OZPN clusters, the cluster radius, $R$, does not depend on the $\mathrm{EtOH}$ concentration in the range $20-90 \%$ (Figure $3 \mathrm{~h}$ ).

\section{The Mesoscopic OZPN-Rich Clusters Do Not Contribute to Crystal Growth}

Classical theories of crystal growth presume that solute monomers sequentially incorporate into the crystals leading to their growth [17,90-95]. The association of mesoscopic OZPN-rich clusters to crystal surfaces could contribute to three nonclassical modes of growth. First, clusters may acquire the structure of the underlying crystal lattice and convert to a stack of new layers, which then grow laterally by incorporation of solute monomers. The enhanced generation of new crystal layers may be very significant for crystals for which few or no dislocation outcrop on the crystal faces and two-dimensional nucleation of new layers is stunted, as seen with the protein lumazine synthase $[19,96]$. Second, the numerous landing clusters may merge into new crystal matter and directly contribute to the mass of the crystal $[9,20,97,98]$. Third, the clusters could dissolve and feed proximal steps.

To test whether clusters partake in the growth of OZPN crystals in any of the three ways, we used AFM to monitor the growth of 2OZPN.EtOH·2 $\mathrm{H}_{2} \mathrm{O}$ crystals [38]. We did not observe integration of the clusters with crystal layers in any way. Clusters deposited on the surface (Figure $4 \mathrm{~b}$ ) retain their distinct structure and can be removed from the surface by 
scratching using increased force on the AFM tip (Figure 4c). Additionally, after removing clusters from the solution by filtration, the step velocities remained unchanged. These two results suggest that the cluster contribution to growth is negligible.
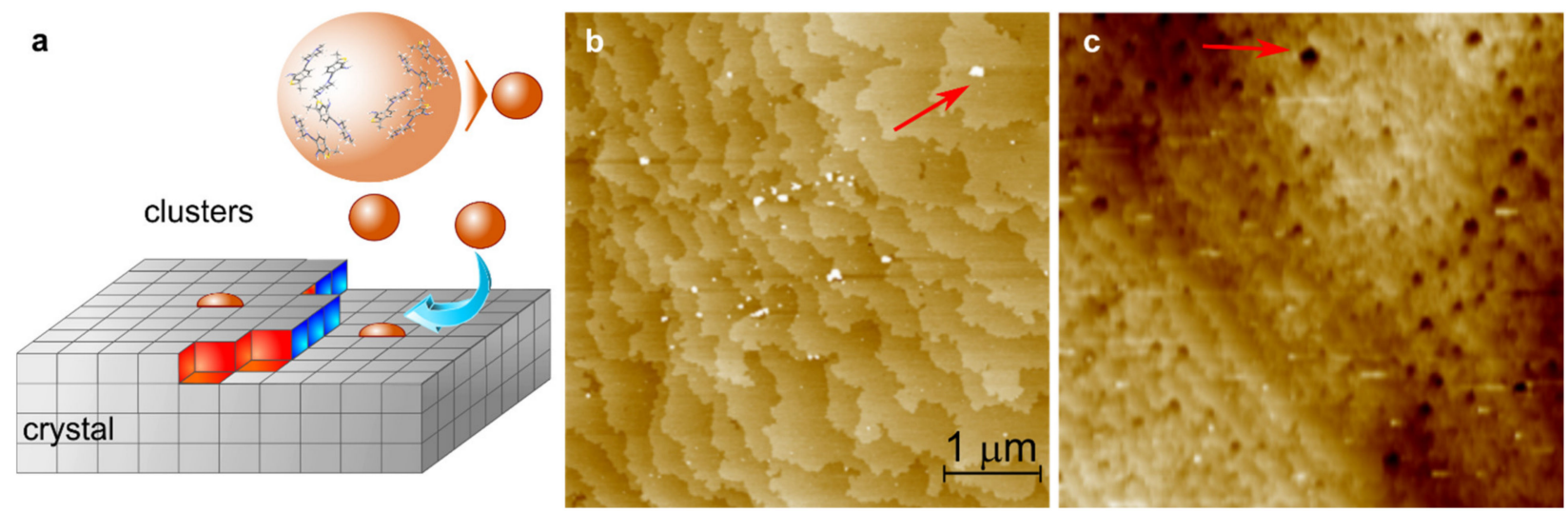

Figure 4. Contribution of mesoscopic solute-rich clusters to OZPN crystal growth. (a) Schematic of. Schematic of the potential contribution. (b) Clusters (indicated with a red arrow) formed in OZPN EtOH/ $\mathrm{H}_{2} \mathrm{O}$ solution land on OZPN crystal surface at $C==2.68 \mathrm{mM}$. (c) Scanning with increased tip force reveals that clusters partially incorporated into the crystal (indicated with a red arrow) etch faster than the underlying crystal, revealing that they do not integrate into the crystal lattice.

\section{Crystal Growth by Incorporation of Preformed Solution Dimers}

Over 60 solvated and non-solvated forms of OZPN have been identified to date; in all of them, save one grown in a polymer dispersion [99], OZPN molecules are organized in a centrosymmetric dimer motif $\mathrm{SC}_{0}$, comprised of two enantiomers (Figure 5a) [25]. The overwhelming dominance of the dimeric unit has spurred speculation that the dimers could form in solutions and serve as a growth unit for OZPN crystal forms [38,100].

To test whether OZPN crystals grow via the incorporation of dimers, we monitored the growth of $2 \mathrm{OZPN} \cdot \mathrm{EtOH} \cdot 2 \mathrm{H}_{2} \mathrm{O}$ crystals from a $1 / 1(v / v)$ ethanol/water mixture using time-resolved in situ AFM [38]. The $\{002\}$ faces grow by incorporation of solute into steps produced by screw dislocations (Figure 5b) [38]. The velocity, $v$, of evolving steps was determined from the slope of step displacement measured as a function of time as OZPN steps grew at steady rates over extended periods. Assuming that steps grow by incorporation of solute monomers [17] implies monomolecular reaction, and gives rise to a linear correlation between $v$ and the solute concentration $C, v=\beta \Omega\left(C-C_{e}\right)$, where subtracting the solubility $C_{e}$ accounts for the reversibility of molecular attachment. Here, $\Omega$ is the molecular volume in the crystal, and $\beta$ is an effective kinetic coefficient, which includes the kinetic parameters for the selected growth mechanism, direct incorporation or via adsorption on the terraces [93,101]. Linear $v(C)$ correlations have been observed for numerous solution-grown crystals [19,102-117]. Unexpectedly, OZPN displays a superlinear $v(C)$ dependence, which extends to concentrations greater than than twice the solubility $C_{e}$ (Figure 1c,d). 
a
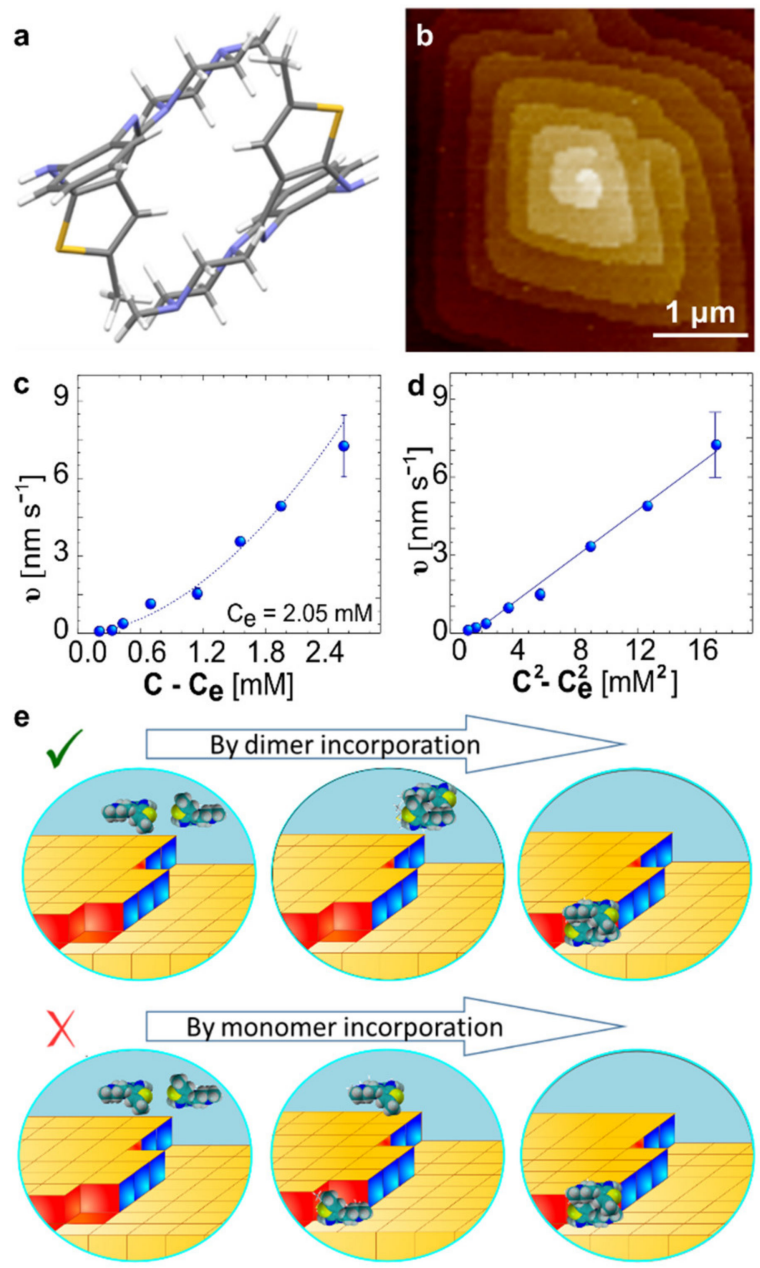

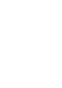


concentration and the step velocity, which accounts for partial or total dimerization of the solute, we consider the equilibrium between two monomers $M$ and a dimer $D$

$$
2 M \rightleftarrows D, \text { for which } K_{D}=C_{D} / C_{M}^{2},
$$

We assume that no higher aggregates form in OZPN solutions than dimers. Then, the molar 1 concentration of OZPN $C$ and the concentrations of monomers $C_{M}$ and dimers $C_{D}$ are related:

$$
2 C_{D}+C_{M}=C
$$

We obtain

$$
\begin{gathered}
C_{M}=\frac{\sqrt{1+8 K_{D} C}-1}{4 K_{D}} \\
\text { and } C_{D}=K_{D} C_{M}^{2}=\frac{1}{16 K_{D}}\left[\sqrt{1+8 K_{D} C}-1\right]^{2}
\end{gathered}
$$

The step velocity $v$ scales with the difference between opposing fluxes: the attachment rate of solute molecules into the kink site $j_{+}$and the detachment rates of the solute molecules from the kink site $j_{-}$.

$$
v=\Omega\left(j_{+}-j_{-}\right)
$$

where $\Omega$ is the molecular volume in the crystal. Using that $[17,95]$,

$$
j_{+}=\frac{D_{i}}{\Lambda_{i}} C_{i}
$$

where $D_{i}$ is the diffusion coefficient and $\Lambda_{i}$, resistance to enter the step. At equilibrium, $v=0$, and

$$
j_{-}=j_{+}=\frac{D_{i}}{\Lambda_{i}} C_{i e}
$$

where $C_{i e}$ is the concentration of the respective species at equilibrium. We obtain

$$
v=\frac{D_{i} \Omega_{\mathrm{i}}}{\Lambda_{i}}\left(C_{i}-C_{i e}\right)
$$

We derive expressions for the step velocity $v$ as a function of total OZPN concentration $C$ for four scenarios that involve dimers present in the growth solution:

1. Monomers dominate in the solution and growth occurs by the attachment of monomers. In this case, Equation (7) transforms into

$$
v=\frac{D_{M} \Omega_{M}}{\Lambda_{M}}\left(C_{M}-C_{M e}\right)
$$

Assuming that the concentration of dimers in the solution is much lower than the concentration of monomers, $C_{D} \ll C_{M}$, the dimerization constant $K_{D} \ll 1 / C_{M}$, $K_{D} C_{M} \ll 1$ and $8 K_{D} C_{M}<1$. With this, Equation (3) transforms to

$$
C_{M}=\frac{1}{8 K_{D}} 8 K_{D} C=C
$$

A linear relationship is expected between step velocity, $v$, and the total OZPN concentration $C$

$$
v=\frac{D_{M} \Omega_{M}}{\Lambda_{M}}\left(C-C_{e}\right) ;
$$


2. Monomers dominate in solution, although growth occurs by attachment dimers. In this case, $C_{D} \ll C_{M}, K_{D} \ll 1 / C_{M}$, and $8 K_{D} C_{M}<1$. Assuming $x=8 K_{D} C$, Equation (4) becomes

$$
C_{D}=\frac{1}{16 K_{D}} \frac{64 K_{D}^{2} C^{2}}{4}=K_{D} C^{2}
$$

We obtain for $j_{+}, j_{-}$, and $v$

$$
\begin{gathered}
j_{+}=\frac{D_{D}}{\Lambda_{\mathrm{D}}} K_{D} C^{2}, j_{-}=j_{e}=\frac{D_{D}}{\Lambda_{\mathrm{D}}} K_{D} C_{e}^{2}, \\
\text { and } v=\frac{D_{D} \Omega_{\mathrm{D}}}{\Lambda_{\mathrm{D}}} K_{D}\left(C^{2}-C_{e}^{2}\right)
\end{gathered}
$$

Equation (9) implies that the correlation between the step velocity and the total solute concentration is quadratic;

3. If dimers dominate in solution but the growth occurs by attachment of monomers, $C_{D} \gg C_{M}$ and $K_{D} \gg 1 / C_{M}, 8 K_{D} C>8 K_{D} C_{M}>1$ and $\sqrt{1+8 K_{D} C}>1$. With this,

$$
C_{M}=\frac{\sqrt{8 K_{D} C}}{4 K_{D}}=\frac{1}{2} \sqrt{\frac{2 C}{K_{D}}}
$$

and, from Equation (9),

$$
v=\frac{D_{M} \Omega_{\mathrm{M}}}{\Lambda_{\mathrm{M}}} \sqrt{\frac{1}{2 K_{D}}}\left(\sqrt{C}-\sqrt{C_{e}}\right)
$$

Equation (8) corresponds to a sublinear dependence between the step velocity and the total solute concentration;

4. If dimers dominate in the solution and associate to the steps, $C_{D} \gg C_{M}$ and $K_{D} \gg 1 / C_{M}, 8 K_{D} C>8 K_{D} C_{M}>1$ and $\sqrt{1+8 K_{D} C}>1$. We obtain

$$
\begin{gathered}
C_{D}=\frac{C}{2} \\
\text { and } v=\frac{D_{D} \Omega_{\mathrm{D}}}{2 \Lambda_{\mathrm{D}}}\left(C-C_{e}\right) .
\end{gathered}
$$

The presented kinetic scheme reveals that if crystals grow by incorporation of solute dimers that exist in equilibrium with monomers, the step velocity would depend on the analytical concentration of the solute $C$ as $v=\beta_{D} K_{D} \Omega_{D}\left(C^{2}-C_{e}^{2}\right)$, where $\beta_{D}=D_{D} / \Lambda_{D}$, the subscript $D$ denotes dimer, and $K_{D}$ is the dimerization equilibrium constant. The $v(C)$ data are consistent with this functional relation (Figure $5 \mathrm{c}, \mathrm{d}$ ).

\section{How Many Dimers Are There in Supersaturated OZPN Solutions?}

We applied Raman spectroscopy to study formation of OZPN dimers in solution. We compare OZPN spectra at low concentration, $0.005 \mathrm{M}$, to spectra at relatively high concentrations, $0.043 \mathrm{M}$, and to spectra of the corresponding solid form, $2 \mathrm{OZPN} \cdot \mathrm{EtOH} \cdot 2 \mathrm{H}_{2} \mathrm{O}$, in which OZPN is arranged as $\mathrm{SC}_{0}$ dimers (Figure $5 \mathrm{a}$ ). To assign the origins of the observed

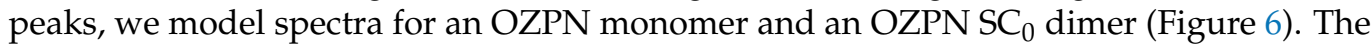
model spectra for the OZPN monomer show multiple Raman peaks between 1200 and $1500 \mathrm{~cm}^{-1}$ (Figure 6), whereas the model spectra for the dimer show strong peaks around $1000 \mathrm{~cm}^{-1}$ and in the range $1500-1600 \mathrm{~cm}^{-1}$ [118]. 


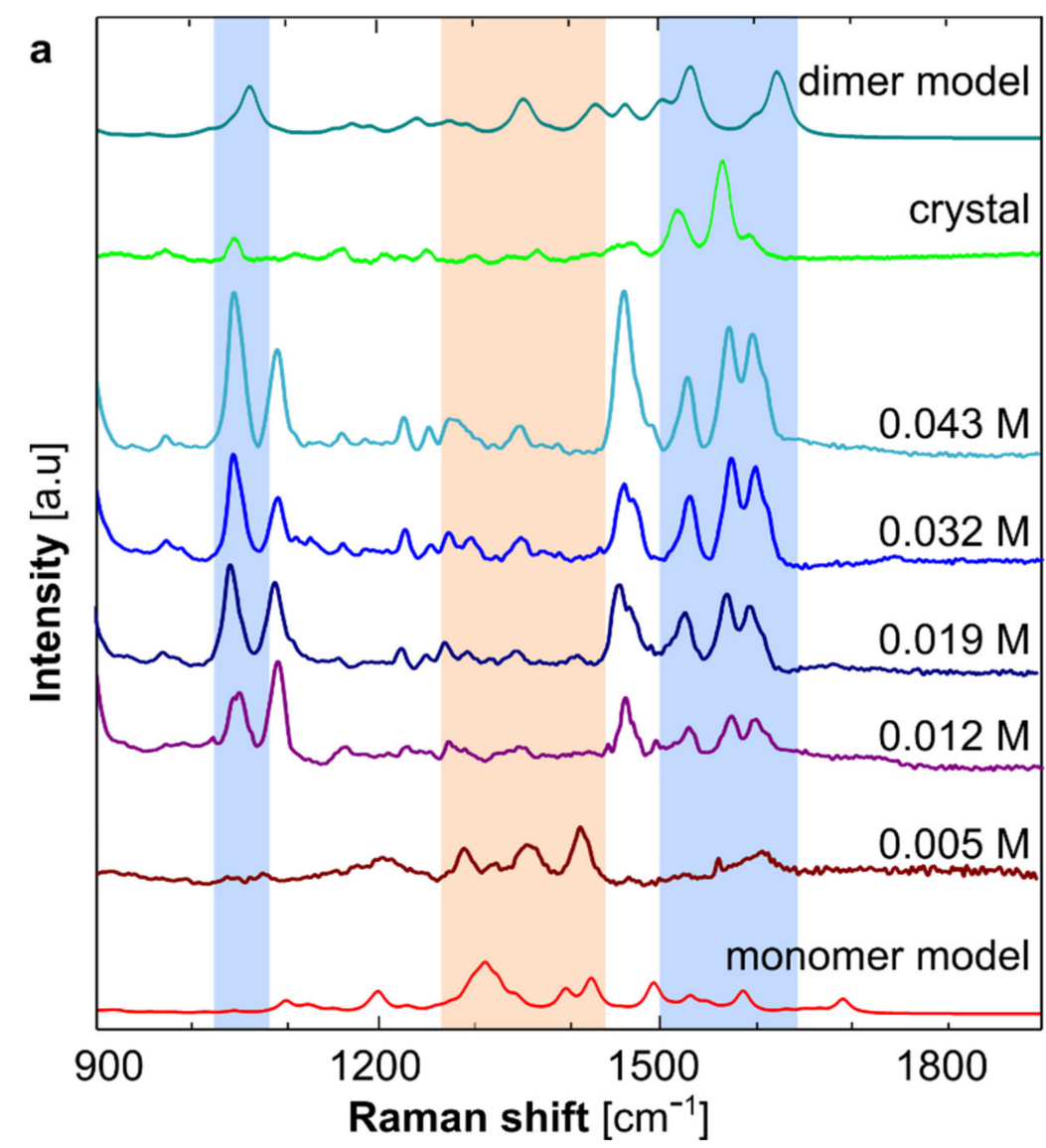

Figure 6. OZPN dimers in solution. Raman spectra of OZPN dissolved in $1 / 1 \mathrm{EtOH} / \mathrm{H}_{2} \mathrm{O}$ at listed concentrations and of the solid crystalline solvate are compared to calculated spectra for OZPN monomer and dimer.

Raman spectra of OZPN water ethanoate solvate crystals show prominent dimer peaks comparable to spectra obtained for solution samples at high concentration. (Figure 6). The low-concentration solution spectra reveal strong monomer peaks and lack of dimer peaks. Raman spectra at increasing intermediate concentrations in both solvents display gradual contraction of the monomer peaks and an increase in intensity of the dimer peaks (Figure 6). The concentration dependence of the monomer and dimer Raman peak intensities enable estimation of the OZPN dimerization constant $K_{D}$. The Raman intensity is directly related to the concentration of the species generating the signal [10].

$$
I=J C
$$

where $J$ is the molar intensity coefficient, and $C$ is the concentration of the respective species.

The band at $1517 \mathrm{~cm}^{-1}$ is related to the dimer, and it preserves its shape at all OZPN concentrations (Figure 6). The intensity of this peak at the highest tested $C$ was selected as an internal intensity standard $I_{s t}$. We test several values of $K_{D}$, and for each value $K_{D}$ we calculate the $C_{D}$ for each of the measured concentrations. We refer to computed $C_{D}$ at the highest $C$ as $C_{D s t}$. The expected intensity of the peak at $1517 \mathrm{~cm}^{-1}$ for each assumed $K_{D}$ was calculated via

$$
I_{D}=\frac{C_{D} I_{s t}}{C_{D s t}}
$$

For each assumed $K_{D}$, the the root mean squared deviation (RMSD) of the computed $I_{D}$ from the experimentally measured values at five different OZPN concentrations was calculated. The $K_{D}$ that yielded the lowest RMSD was taken as the best estimate of the dimerization constant. We obtain $K_{D}=2.7 \pm 0.1 \mathrm{M}^{-1}$. Mass balance calculations inform 
that the dimer concentration $C_{D}$ in the growth solution is $0.01 \mathrm{mM}$ at the solubility $2.05 \mathrm{mM}$; $C_{D}$ increases to $0.05 \mathrm{mM}$ at the highest tested total OZPN concentration in the growth studies, $C=4.45 \mathrm{mM}$ (Figure $5 \mathrm{c}$ ). The superlinear increase in $C_{D}$ dictates the quadratic $v(C)$ correlation (Figure $5 \mathrm{c}, \mathrm{d}$ ).

\section{From Dimers to Clusters and Crystal Nucleation}

Given the self-association of OZPN dimers in the growth solution and the widespread dimeric motif in the $2 \mathrm{OZPN} \cdot \mathrm{EtOH} \cdot 2 \mathrm{H}_{2} \mathrm{O}$ crystals, it is reasonable to assume that the solute dimers are selected during crystal nucleation, i.e., OZPN crystals nucleate by association of preexisting dimers faster than the same structure would nucleate by assembly of individual molecules. This argument cannot be true, however, if nucleation follows the classical pathway of sequential association of individual or dimerized molecules. Indeed, classical nucleation theory identifies two powerful parameters of the nucleation rate: the surface tension between the emerging nucleus and the host solution, and the supersaturation. The surface tension cannot distinguish between the two nucleation pathways as it is prescribed by the structures of the respective nuclei, which are identical. Simple mass balance calculations, based on the value of the dimerization constant $K_{D}=2.7 \mathrm{M}^{-1}$, indicate that the concentration of the dimers would be much higher than that of the monomers only if the total OZPN concentration is greater than 1.1 M. Crystals nucleate at concentrations several-fold greater than the solubility $C_{e}=2.05 \mathrm{mM}$, i.e., of order $10 \mathrm{mM}$, at which the monomers are in high excess. Thus, supersaturation favors classical nucleation by assembly of individual molecules.

By contrast, evidence presented above suggests that nucleation pathway of OZPN crystals follows two-step process where the crystal nucleation is hosted and assisted by prenucleation phase (Figures 2-4) [38]. The unique cluster properties differentiate them from other condensed phases; these behaviors have been related to the formation, diffusion, and decay of transient OZPN dimers that prompt cluster formation and gather in the clusters $[54,55,65,86,120]$. The high concentration in the clusters of transient dimers, which are akin to the crystallographic centrosymmetric dimers, may facilitate their restructuring and assembly into a crystal nucleus comprised of dimers [121,122].

\section{Summary and Conclusions}

Our results test the role of two crystallization precursors, solute dimers and soluterich liquid clusters, in the crystallization of olanzapine. We show that that the clusters are abundant in the solution, where they facilitate the nucleation of crystal forms. The clusters, however, incorporate in the crystal as foreign bodies and, in distinction to numerous other crystallization systems, do not contribute to growth. This finding rejects an emerging paradigm in the field of nonclassical crystallization, that the presence of precursors in the growth medium proves their direct participation in growth.

Crystal growth by the association of monomers to unique growth sites, the kinks, has been viewed as the classical growth mode since it was adopted in the founding papers in the field. Recent observations, however, in biological, geological, and synthetic environments, have put forth cases of non-classical crystallization employing liquid, amorphous, and crystalline precursors. We demonstrate that crystals grow predominantly by incorporation of solute dimers, the simplest preformed units, a growth mode, which has been left out of a notable summary of non-classical crystallization modes [9] as, although it has been inferred from crystal and solute structures, it has never been directly observed experimentally. The finding of growth by dimer incorporation is essential for modelling of crystal properties such as crystal shape [100] and dictates critical modification in ubiquitous crystallization process models that assume that the step growth rate scales linearly with solute concentration Furthermore, studies of the nucleation and polymorph and/or solvate transformation pathways directed by the clusters are essential to understand how to control crystallization outcomes, especially the control of crystal forms. 
Author Contributions: Conceptualization, P.G.V., A.J.F. and M.W. investigation, M.W.; writingoriginal draft preparation, P.G.V.; writing—review and editing, M.W. and A.J.F.; funding acquisition, A.J.F. and P.G.V. All authors have read and agreed to the published version of the manuscript.

Funding: This research was funded by National Science Foundation (Award No. DMR-1710354).

Data Availability Statement: The datasets generated during and/or analyzed during the current study are available from the corresponding authors upon reasonable request.

Acknowledgments: The authors acknowledge the CMAC National Facility, housed within the University of Strathclyde's Technology and Innovation Centre, and funded with a UKRPIF (UK Research Partnership Investment Fund) capital award, SFC ref H13054, from the Higher Education Funding Council for England (HEFCE) and the EPSRC Future Continuous Manufacturing and Advanced Crystallisation Research Hub (Grant Ref: EP/P006965/1).

Conflicts of Interest: The authors declare no conflict of interest.

\section{References}

1. Gibbs, J.W. On the equilibrium of heterogeneous substances, First Part. Trans. Connect. Acad. Sci. 1876, 3, 108-248.

2. Turnbull, D. Kinetics of solidification of supercooled liquid mercury droplets. J. Chem. Phys. 1952, 20, 411-424. [CrossRef]

3. Auer, S.; Frenkel, D. Prediction of absolute crystal-nucleation rate in hard-sphere colloids. Nature 2001, 409, 1020-1023. [CrossRef] [PubMed]

4. Farkas, L. Keimbildungsgeschwindigkeit in übersättigten Dämpfen. Z. Phys. Chem. 1927, 125, 236-242. [CrossRef]

5. Vekilov, P.G. Nonclassical nucleation. In Crystallization via Nonclassical Pathways Volume 1: Nucleation, Assembly, Observation E Application; ACS Symposium Series; American Chemical Society: Washington, DC, USA, 2020; Volume 1358, pp. 19-46.

6. Brunner, J.; Cölfen, H. Progress in mesocrystal formation. In Crystallization via Nonclassical Pathways Volume 1: Nucleation, Assembly, Observation \& Application; ACS Symposium Series; American Chemical Society: Washington, DC, USA, 2020; Volume 1358, pp. 73-96.

7. Vekilov, P.G. The two-step mechanism of nucleation of crystals in solution. Nanoscale 2010, 2, 2346-2357. [CrossRef] [PubMed]

8. De Yoreo, J. A Perspective on multistep pathways of nucleation. In Crystallization via Nonclassical Pathways Volume 1: Nucleation, Assembly, Observation E Application; ACS Symposium Series; American Chemical Society: Washington, DC, USA, 2020; Volume 1358, pp. 1-17.

9. De Yoreo, J.J.; Gilbert, P.U.P.A.; Sommerdijk, N.A.J.M.; Penn, R.L.; Whitelam, S.; Joester, D.; Zhang, H.; Rimer, J.D.; Navrotsky, A.; Banfield, J.F.; et al. Crystallization by particle attachment in synthetic, biogenic, and geologic environments. Science 2015, 349, aaa6760. [CrossRef]

10. Galkin, O.; Chen, K.; Nagel, R.L.; Hirsch, R.E.; Vekilov, P.G. Liquid-liquid separation in solutions of normal and sickle cell hemoglobin. Proc. Natl. Acad. Sci. USA 2002, 99, 8479-8483. [CrossRef]

11. Yamazaki, T.; Kimura, Y.; Vekilov, P.G.; Furukawa, E.; Shirai, M.; Matsumoto, H.; Van Driessche, A.E.S.; Tsukamoto, K. Two types of amorphous protein particles facilitate crystal nucleation. Proc. Natl. Acad. Sci. USA 2017, 114, 2154-2159. [CrossRef]

12. Ma, X.; Zhang, S.; Jiao, F.; Newcomb, C.J.; Zhang, Y.; Prakash, A.; Liao, Z.; Baer, M.D.; Mundy, C.J.; Pfaendtner, J.; et al. Tuning crystallization pathways through sequence engineering of biomimetic polymers. Nat. Mater. 2017, 16, 767. [CrossRef]

13. Stranski, I.N. Zur theorie des kristallwachstums. Z. Phys. Chem. 1928, 136, 259-278. [CrossRef]

14. Blüh, O. Einige bei der Untersuchung von Kolloiden im Wechselfeld auftretende Erscheinungen. Kolloid Z. 1925, 37, 267-270. [CrossRef]

15. Schaskolsky, M.; Schubnikow, A. Über die künstliche Herstellung gesetzmäßiger Kristallverwachsungen des Kalialauns. Z. Für Krist. Cryst. Mater. 1933, 85, 1. [CrossRef]

16. Volmer, M. Kinetik der Phasenbildung; Steinkopff: Dresden, Germany, 1939; p. 208.

17. Burton, W.K.; Cabrera, N.; Frank, F.C. The growth of crystals and equilibrium structure of their surfaces. Phil. Trans. Roy. Soc. Lond. Ser. A 1951, 243, 299-360.

18. Bennema, P. Analysis of crystal growth models for slightly supersaturated solutions. J. Cryst. Growth 1967, 1, 278-286. [CrossRef]

19. Gliko, O.; Neumaier, N.; Pan, W.; Haase, I.; Fischer, M.; Bacher, A.; Weinkauf, S.; Vekilov, P.G. A metastable prerequisite for the growth of lumazine synthase crystals. J. Amer. Chem. Soc. 2005, 127, 3433-3438. [CrossRef] [PubMed]

20. Li, D.; Nielsen, M.H.; Lee, J.R.I.; Frandsen, C.; Banfield, J.F.; De Yoreo, J.J. Direction-specific interactions control crystal growth by oriented attachment. Science 2012, 336, 1014-1018. [CrossRef]

21. Baumgartner, J.; Dey, A.; Bomans, P.H.H.; Le Coadou, C.; Fratzl, P.; Sommerdijk, N.A.J.M.; Faivre, D. Nucleation and growth of magnetite from solution. Nat. Mater. 2013, 12, 310. [CrossRef]

22. Coelfen, H.; Antionetti, M. Mesocrystals and Nonclassical Crystallization; John Wiley \& Sons: New York, NY, USA, 2008.

23. Lee, S.; Wi, H.S.; Jo, W.; Cho, Y.C.; Lee, H.H.; Jeong, S.-Y.; Kim, Y.-I.; Lee, G.W. Multiple pathways of crystal nucleation in an extremely supersaturated aqueous potassium dihydrogen phosphate (KDP) solution droplet. Proc. Natl. Acad. Sci. USA 2016, 113, 13618-13623. [CrossRef] [PubMed]

24. Fulton, B.; Goa, K.L. Olanzapine. Drugs 1997, 53, 281-298. [CrossRef] [PubMed] 
25. Bhardwaj, R.M.; Price, L.S.; Price, S.L.; Reutzel-Edens, S.M.; Miller, G.J.; Oswald, I.D.H.; Johnston, B.F.; Florence, A.J. Exploring the experimental and computed crystal energy landscape of olanzapine. Cryst. Growth Des. 2013, 13, 1602-1617. [CrossRef]

26. Ostwald, W. Studien über die Bildung und Umwandlung fester Körper. Z. Phys. Chem. 1897, 22, 289-330. [CrossRef]

27. Müller, M.; Meier, U.; Wieckhusen, D.; Beck, R.; Pfeffer-Hennig, S.; Schneeberger, R. Process development strategy to ascertain reproducible API polymorph manufacture. Cryst. Growth Des. 2006, 6, 946-954. [CrossRef]

28. Kirwan, D.J.; Orella, C.J. Crystallization in the pharmaceutical and bioprocessing industries. In Handbook of Industrial Crystallization; Myerson, A.S., Ed.; Butterworth-Heinemann: Oxford, UK, 2002.

29. Cherukuvada, S.; Babu, N.J.; Nangia, A. Nitrofurantoin-p-aminobenzoic acid cocrystal: Hydration stability and dissolution rate studies. J. Pharm. Sci. 2011, 100, 3233-3244. [CrossRef]

30. Reutzel-Edens, S.M.; Bush, J.K.; Magee, P.A.; Stephenson, G.A.; Byrn, S.R. Anhydrates and hydrates of olanzapine: crystallization, solid-state characterization, and structural relationships. Cryst. Growth Des. 2003, 3, 897-907. [CrossRef]

31. Bernstein, J. Polymorphism in Molecular Crystals; Oxford University Press: Oxford, UK, 2007.

32. Blagden, N.; Davey, R.J. Polymorph Selection: Challenges for the Future? Cryst. Growth Des. 2003, 3, 873-885. [CrossRef]

33. Kapishnikov, S.; Grolimund, D.; Schneider, G.; Pereiro, E.; McNally, J.G.; Als-Nielsen, J.; Leiserowitz, L. Unraveling heme detoxification in the malaria parasite by in situ correlative X-ray fluorescence microscopy and soft X-ray tomography. Sci. Rep. 2017, 7, 7610. [CrossRef]

34. Huang, J.; Stringfellow, T.C.; Yu, L. Glycine exists mainly as monomers, not dimers, in supersaturated aqueous solutions: Implications for understanding its crystallization and polymorphism. J. Am. Chem. Soc. 2008, 130, 13973-13980. [CrossRef]

35. Wawrzycka-Gorczyca, I.; Borowski, P.; Osypiuk-Tomasik, J.; Mazur, L.; Koziol, A. Crystal structure of olanzapine and its solvates. Part 3. Two and three-component solvates with water, ethanol, butan-2-ol and dichloromethane. J. Mol. Struct. 2007, 830, 188-197. [CrossRef]

36. Carletta, A.; Meinguet, C.; Wouters, J.; Tilborg, A. Solid-State Investigation of Polymorphism and Tautomerism of Phenylthiazolethione: A Combined Crystallographic, Calorimetric, and Theoretical Survey. Cryst. Growth Des. 2015, 15, 2461-2473. [CrossRef]

37. Koster, R.S.; Fang, C.; van Blaaderen, A.; Dijkstra, M.; van Huis, M.A. Acetate ligands determine the crystal structure of CdSe nanoplatelets-A density functional theory study. Phys. Chem. Chem. Phys. 2016, 18, 22021-22024. [CrossRef]

38. Warzecha, M.; Guo, R.; Bhardwaj, R.M.; Reutzel-Edens, S.M.; Price, S.L.; Lamprou, D.A.; Florence, A.J. Direct Observation of Templated Two-Step Nucleation Mechanism during Olanzapine Hydrate Formation. Cryst. Growth Des. 2017, 17, 6382-6393. [CrossRef]

39. Pan, W.; Kolomeisky, A.B.; Vekilov, P.G. Nucleation of ordered solid phases of protein via a disordered high-density state: Phenomenological approach. J. Chem. Phys. 2005, 122, 174905. [CrossRef]

40. Kashchiev, D.; Vekilov, P.G.; Kolomeisky, A.B. Kinetics of two-step nucleation of crystals. J. Chem. Phys. 2005, 122, 244706. [CrossRef]

41. Durán-Olivencia, M.A.; Yatsyshin, P.; Kalliadasis, S.; Lutsko, J.F. General framework for nonclassical nucleation. N. J. Phys. 2018, 20, 083019. [CrossRef]

42. Volmer, M.; Schultze, W. Kondensation an Kristallen. Z. Phys. Chem. 1931, 156A, 1-22. [CrossRef]

43. Neilsen, A.E. Nucleation in aqueous solutions. In Crystal Growth; Peiser, S., Ed.; Pergamon: Oxford, UK, $1967 ;$ pp. $419-426$.

44. Walton, A.G. Nucleation in liquids and solutions. In Nucleation; Zettlemoyer, A.C., Ed.; Marcel Dekker: New York, NY, USA, 1969; pp. 225-307.

45. Vekilov, P.G. Dense liquid precursor for the nucleation of ordered solid phases from solution. Cryst. Growth Des. 2004, 4, 671-685. [CrossRef]

46. Garetz, B.; Matic, J.; Myerson, A. Polarization switching of crystal structure in the nonphotochemical light-induced nucleation of supersaturated aqueous glycine solutions. Phys. Rev. Lett. 2002, 89, 175501. [CrossRef]

47. Erdemir, D.; Lee, A.Y.; Myerson, A.S. Nucleation of Crystals from Solution: Classical and Two-Step Models. Acc. Chem. Res. 2009, 42, 621-629. [CrossRef] [PubMed]

48. Vorontsova, M.A.; Maes, D.; Vekilov, P.G. Recent advances in the understanding of two-step nucleation of protein crystals. Faraday Discuss. 2015, 179, 27-40. [CrossRef]

49. Vekilov, P.G. Nucleation. Cryst. Growth Des. 2010, 10, 5007-5019. [CrossRef] [PubMed]

50. Auer, S.; Ricchiuto, P.; Kashchiev, D. Two-step nucleation of amyloid fibrils: Omnipresent or not? J. Mol. Biol. 2012, 422, 723-730. [CrossRef]

51. Sauter, A.; Roosen-Runge, F.; Zhang, F.; Lotze, G.; Feoktystov, A.; Jacobs, R.M.J.; Schreiber, F. On the question of two-step nucleation in protein crystallization. Faraday Discuss. 2015, 179, 41-58. [CrossRef] [PubMed]

52. Schubert, R.; Meyer, A.; Baitan, D.; Dierks, K.; Perbandt, M.; Betzel, C. Real-Time Observation of Protein Dense Liquid Cluster Evolution during Nucleation in Protein Crystallization. Cryst. Growth Des. 2017, 17, 954-958. [CrossRef]

53. Saric, A.; Chebaro, Y.C.; Knowles, T.P.J.; Frenkel, D. Crucial role of nonspecific interactions in amyloid nucleation. Proc. Natl. Acad. Sci. USA 2014, 111, 17869-17874. [CrossRef] [PubMed]

54. Yang, D.S.; Saeedi, A.; Davtyan, A.; Fathi, M.; Sherman, M.B.; Safari, M.S.; Klindziuk, A.; Barton, M.C.; Varadarajan, N.; Kolomeisky, A.B.; et al. Mesoscopic protein-rich clusters host the nucleation of mutant p53 amyloid fibrils. Proc. Natl. Acad. Sci. USA 2021, 118, e2015618118. [CrossRef] 
55. Safari, M.S.; Wang, Z.; Tailor, K.; Kolomeisky, A.B.; Conrad, J.C.; Vekilov, P.G. Anomalous Dense Liquid Condensates Host the Nucleation of Tumor Suppressor p53 Fibrils. iScience 2019, 12, 342-355. [CrossRef]

56. Savage, J.R.; Dinsmore, A.D. Experimental Evidence for Two-Step Nucleation in Colloidal Crystallization. Phys. Rev. Lett. 2009, 102, 198302. [CrossRef]

57. Zhang, T.H.; Liu, X.Y. Multistep crystal nucleation: A kinetic study based on colloidal crystallization. J. Phys. Chem. B 2007, 111, 14001-14005. [CrossRef]

58. Likhatski, M.; Karacharov, A.; Kondrasenko, A.; Mikhlin, Y. On a role of liquid intermediates in nucleation of gold sulfide nanoparticles in aqueous media. Faraday Discuss. 2015, 179, 235-245. [CrossRef]

59. Gebauer, D.; Kellermeier, M.; Gale, J.D.; Bergstrom, L.; Colfen, H. Pre-nucleation clusters as solute precursors in crystallisation. Chem Soc. Rev. 2014, 43, 2348-2371. [CrossRef]

60. De Yoreo, J. Crystal nucleation: More than one pathway. Nat. Mater. 2013, 12, 284-285. [CrossRef] [PubMed]

61. Dey, A.; Bomans, P.H.H.; Müller, F.A.; Will, J.; Frederik, P.M.; de With, G.; Sommerdijk, N.A.J.M. The role of prenucleation clusters in surface-induced calcium phosphate crystallization. Nat. Mater. 2010, 9, 1010-1014. [CrossRef] [PubMed]

62. Aber, J.E.; Arnold, S.; Garetz, B.A. Strong dc Electric Field Applied to Supersaturated Aqueous Glycine Solution Induces Nucleation of the Polymorph. Phys. Rev. Lett. 2005, 94, 145503. [CrossRef] [PubMed]

63. Harano, K.; Homma, T.; Niimi, Y.; Koshino, M.; Suenaga, K.; Leibler, L.; Nakamura, E. Heterogeneous nucleation of organic crystals mediated by single-molecule templates. Nat. Mater. 2012, 11, 877-881. [CrossRef]

64. Bonnett, P.E.; Carpenter, K.J.; Dawson, S.; Davey, R.J. Solution crystallization via a submerged liquid-liquid phase boundary: Oiling out. Chem. Commun. 2003, 6, 698-699. [CrossRef]

65. Pan, W.; Vekilov, P.G.; Lubchenko, V. The origin of anomalous mesoscopic phases in protein solutions. J. Phys. Chem. B 2010, 114, 7620-7630. [CrossRef]

66. Vorontsova, M.A.; Chan, H.Y.; Lubchenko, V.; Vekilov, P.G. Lack of Dependence of the Sizes of the Mesoscopic Protein Clusters on Electrostatics. Biophys. J. 2015, 109, 1959-1968. [CrossRef]

67. Li, Y.; Lubchenko, V.; Vekilov, P.G. The Use of Dynamic Light Scattering and Brownian Microscopy to Characterize Protein Aggregation. Rev. Sci. Instrum. 2011, 82, 053106. [CrossRef]

68. Vorontsova, M.A.; Vekilov, P.G.; Maes, D. Characterization of the diffusive dynamics of particles with time-dependent asymmetric microscopy intensity profiles. Soft Matter 2016, 12, 6926-6936. [CrossRef]

69. Chaikin, P.M.; Lubensky, T.C. Principles of Condensed Matter Physics; Cambridge Unversity Press: Cambridge, UK, 1995.

70. Hutchens, S.B.; Wang, Z.-G. Metastable cluster intermediates in the condensation of charged macromolecule solutions. J. Chem. Phys. 2007, 127, 084912. [CrossRef]

71. Stradner, A.; Sedgwick, H.; Cardinaux, F.; Poon, W.C.K.; Egelhaaf, S.U.; Schurtenberger, P. Equilibrium cluster formation in concentrated protein solutions and colloids. Nature 2004, 432, 492-495. [CrossRef]

72. Porcar, L.; Falus, P.; Chen, W.-R.; Faraone, A.; Fratini, E.; Hong, K.; Baglioni, P.; Liu, Y. Formation of the Dynamic Clusters in Concentrated Lysozyme Protein Solutions. J. Phys. Chem. Lett. 2009, 1, 126-129. [CrossRef]

73. Erlkamp, M.; Grobelny, S.; Faraone, A.; Czeslik, C.; Winter, R. Solvent Effects on the Dynamics of Amyloidogenic Insulin Revealed by Neutron Spin Echo Spectroscopy. J. Phys. Chem. B 2014, 118, 3310-3316. [CrossRef]

74. Johnston, K.P.; Maynard, J.A.; Truskett, T.M.; Borwankar, A.U.; Miller, M.A.; Wilson, B.K.; Dinin, A.K.; Khan, T.A.; Kaczorowski, K.J. Concentrated Dispersions of Equilibrium Protein Nanoclusters That Reversibly Dissociate into Active Monomers. ACS Nano 2012, 6, 1357-1369. [CrossRef]

75. Borwankar, A.U.; Dinin, A.K.; Laber, J.R.; Twu, A.; Wilson, B.K.; Maynard, J.A.; Truskett, T.M.; Johnston, K.P. Tunable equilibrium nanocluster dispersions at high protein concentrations. Soft Matter 2013, 9, 1766-1771. [CrossRef]

76. Soraruf, D.; Roosen-Runge, F.; Grimaldo, M.; Zanini, F.; Schweins, R.; Seydel, T.; Zhang, F.; Roth, R.; Oettel, M.; Schreiber, F. Protein cluster formation in aqueous solution in the presence of multivalent metal ions-A light scattering study. Soft Matter 2014, 10, 894-902. [CrossRef] [PubMed]

77. Yearley, E.J.; Godfrin, P.D.; Perevozchikova, T.; Zhang, H.; Falus, P.; Porcar, L.; Nagao, M.; Curtis, J.E.; Gawande, P.; Taing, R.; et al. Observation of Small Cluster Formation in Concentrated Monoclonal Antibody Solutions and Its Implications to Solution Viscosity. Biophys. J. 2014, 106, 1763-1770. [CrossRef]

78. Cardinaux, F.; Stradner, A.; Schurtenberger, P.; Sciortino, F.; Zaccarelli, E. Modeling equilibrium clusters in lysozyme solutions. EPL (Europhys. Lett.) 2007, 77, 48004. [CrossRef]

79. Li, Y.; Lubchenko, V.; Vorontsova, M.A.; Filobelo, L.; Vekilov, P.G. Ostwald-Like Ripening of the Anomalous Mesoscopic Clusters in Protein Solutions. J. Phys. Chem. B 2012, 116, 10657-10664. [CrossRef] [PubMed]

80. Gliko, O.; Pan, W.; Katsonis, P.; Neumaier, N.; Galkin, O.; Weinkauf, S.; Vekilov, P.G. Metastable liquid clusters in super- and undersaturated protein solutions. J. Phys. Chem. B 2007, 111, 3106-3114. [CrossRef] [PubMed]

81. Sleutel, M.; Van Driessche, A.E. Role of clusters in nonclassical nucleation and growth of protein crystals. Proc. Natl. Acad. Sci. USA 2014, 111, E546-E553. [CrossRef]

82. Uzunova, V.V.; Pan, W.; Galkin, O.; Vekilov, P.G. Free heme and the polymerization of sickle cell hemoglobin. Biophys. J. 2010, 99, 1976-1985. [CrossRef]

83. Chan, H.Y.; Lankevich, V.; Vekilov, P.G.; Lubchenko, V. Anisotropy of the Coulomb Interaction between Folded Proteins: Consequences for Mesoscopic Aggregation of Lysozyme. Biophys. J. 2012, 102, 1934-1943. [CrossRef] [PubMed] 
84. Bhardwaj, R.M.; Reutzel-Edens, S.M.; Johnston, B.F.; Florence, A.J. A random forest model for predicting crystal packing of olanzapine solvates. Cryst. Eng. Comm. 2018, 20, 3947-3950. [CrossRef]

85. Byington, M.C.; Safari, M.S.; Lubchenko, V.; McCabe, J.W.; Angel, L.A.; Hawke, D.H.; Bark, S.J.; Conrad, J.C.; Vekilov, P.G. Weakly-bound Dimers that Underlie the Crystal Nucleation Precursors in Lysozyme Solutions. bioRxiv 2018, 275222. [CrossRef]

86. Chan, H.Y.; Lubchenko, V. A mechanism for reversible mesoscopic aggregation in liquid solutions. Nat. Commun. 2019, 10, 2381. [CrossRef] [PubMed]

87. Rajagopalan, S.; Huang, F.; Fersht, A.R. Single-Molecule characterization of oligomerization kinetics and equilibria of the tumor suppressor p53. Nucleic Acids Res. 2011, 39, 2294-2303. [CrossRef] [PubMed]

88. Xu, J.; Reumers, J.; Couceiro, J.R.; De Smet, F.; Gallardo, R.; Rudyak, S.; Cornelis, A.; Rozenski, J.; Zwolinska, A.; Marine, J.-C.; et al. Gain of function of mutant p53 by coaggregation with multiple tumor suppressors. Nat. Chem. Biol. 2011, 7, 285-295. [CrossRef]

89. Safari, M.S.; Byington, M.C.; Conrad, J.C.; Vekilov, P.G. Polymorphism of Lysozyme Condensates. J. Phys. Chem. B 2017, 121, 9091-9101. [CrossRef] [PubMed]

90. Stranski, I.N.; Kaischew, R. Über den Mechanismus des Gleichgewichtes kleiner Kriställchen. II. Z. Phys. Chem. B 1934, 26, 114-116.

91. Stranski, I.N.; Kaischew, R. Über den Mechanismus des Gleichgewichtes kleiner Kriställchen. I. Z. Phys. Chem. B 1934, 26, 100-113. [CrossRef]

92. Kaischew, R. Zur Theorie des Kristallwaschstums. Z. Phys. 1936, 102, 684-690. [CrossRef]

93. Chernov, A.A. Modern Crystallography III, Crystal Growth; Springer: Berlin/Heidelberg, Germany, 1984.

94. Chernov, A.A. The spiral growth of crystals. Sov. Phys. Uspekhi 1961, 4, 116-148. [CrossRef]

95. Markov, I.V. Crystal Growth for Beginners: Fundamentals of Nucleation, Crystal Growth and Epitaxy; World Scientific Publishing Company Incorporated: Singapore, 2016.

96. Gliko, O.; Neumaier, N.; Pan, W.; Haase, I.; Fischer, M.; Bacher, A.; Weinkauf, S.; Vekilov, P.G. Dense liquid droplets as a step source for the crystallization of lumazine synthase. J. Cryst. Growth 2005, 275, e1409-e1416. [CrossRef]

97. Lupulescu, A.I.; Rimer, J.D. In Situ Imaging of Silicalite-1 Surface Growth Reveals the Mechanism of Crystallization. Science 2014, 344, 729-732. [CrossRef] [PubMed]

98. Kumar, M.; Luo, H.; Román-Leshkov, Y.; Rimer, J.D. SSZ-13 Crystallization by Particle Attachment and Deterministic Pathways to Crystal Size Control. J. Am. Chem. Soc. 2015, 137, 13007-13017. [CrossRef]

99. Askin, S.; Cockcroft, J.K.; Price, L.S.; Gonçalves, A.D.; Zhao, M.; Tocher, D.A.; Williams, G.R.; Gaisford, S.; Craig, D.Q.M. Olanzapine Form IV: Discovery of a New Polymorphic Form Enabled by Computed Crystal Energy Landscapes. Cryst. Growth Des. 2019, 19, 2751-2757. [CrossRef]

100. Sun, Y.; Tilbury, C.J.; Reutzel-Edens, S.M.; Bhardwaj, R.M.; Li, J.; Doherty, M.F. Modeling Olanzapine Solution Growth Morphologies. Cryst. Growth Des. 2018, 18, 905-911. [CrossRef]

101. Gilmer, G.H.; Ghez, R.; Cabrera, N. An analysis of combined volume and surface diffusion processes in crystal growth. J. Cryst. Growth 1971, 8, 79-93. [CrossRef]

102. De Yoreo, J.J.; Vekilov, P.G. Principles of crystal nucleation and growth; Biomineralization. Rev. Mineral. Geochem. 2003, 54, 57-93. [CrossRef]

103. De Yoreo, J.J.; Land, T.A.; Dair, B. Growth morphology of vicinal hillocks on the $\{101\}$ face of KH2PO4: From step flow to layer-by-layer growth. Phys. Rev. Lett. 1994, 73, 838-841. [CrossRef]

104. Land, T.A.; Malkin, A.J.; Kuznetsov, Y.G.; McPherson, A.; Deyoreo, J.J. Mechanisms of protein crystal growth-An atomic force microscopy study of canavalin crystallization. Phys. Rev. Lett. 1995, 75, 2774-2777. [CrossRef]

105. Teng, H.H.; Dove, P.M.; Orme, C.A.; De Yoreo, J.J. Thermodynamics of calcite growth: Baseline for understanding biomineral formation. Science 1998, 282, 724-727. [CrossRef]

106. Land, T.A.; Martin, T.L.; Potapenko, S.; Palmore, G.T.; De Yoreo, J.J. Recovery of surfaces from impurity poisoning during crystal growth. Nature 1999, 399, 442-445. [CrossRef]

107. Kuznetsov, Y.G.; Chernov, A.A.; Vekilov, P.G.; Smol'skii, I.L. Kinetics of growth of (101) faces of $\mathrm{NH}_{4} \mathrm{H}_{2} \mathrm{PO}_{4}$ crystals from aqueous solutions. Sov. Phys. Crystallogr. 1987, 32, 584-587.

108. Vekilov, P.G.; Kuznetsov, Y.G.; Chernov, A.A. Interstep interaction in solution growth; (101) ADP face. J. Cryst. Growth 1992, 121, 643-655. [CrossRef]

109. Vekilov, P.G.; Kuznetsov, Y.G.; Chernov, A.A. The effect of temperature on step motion; (101) ADP face. J. Cryst. Growth 1992, 121, 44-52. [CrossRef]

110. Vekilov, P.G. Elementary processes of protein crystal growth. In Studies and Concepts in Crystal Growth; Komatsu, H., Ed.; Pergamon: Oxford, UK, 1993; pp. 25-49.

111. Vekilov, P.G.; Rosenberger, F. Dependence of lysozyme growth kinetics on step sources and impurities. J. Cryst. Growth 1996, 158, 540-551. [CrossRef]

112. Vekilov, P.G.; Rosenberger, F. Protein crystal growth under forced solution flow: Experimental setup and general response of lysozyme. J. Cryst. Growth 1998, 186, 251-261. [CrossRef]

113. Yau, S.-T.; Petsev, D.N.; Thomas, B.R.; Vekilov, P.G. Molecular-level thermodynamic and kinetic parameters for the self-assembly of apoferritin molecules into crystals. J. Mol. Biol. 2000, 303, 667-678. [CrossRef] 
114. Yau, S.-T.; Thomas, B.R.; Vekilov, P.G. Molecular mechanisms of crystallization and defect formation. Phys. Rev. Lett. 2000, 85, 353-356. [CrossRef] [PubMed]

115. Gliko, O.; Reviakine, I.; Vekilov, P.G. Stable Equidistant Step Trains during Crystallization of Insulin. Phys. Rev. Lett 2003, 90, 225503. [CrossRef] [PubMed]

116. Petsev, D.N.; Chen, K.; Gliko, O.; Vekilov, P.G. Diffusion-limited kinetics of the solution-solid phase transition of molecular substances. Proc. Natl. Acad. Sci. USA 2003, 100, 792-796. [CrossRef]

117. Qutub, Y.; Reviakine, I.; Maxwell, C.; Navarro, J.; Landau, E.M.; Vekilov, P.G. Crystallization of Transmembrane Proteins in cubo: Mechanisms of Crystal Growth and Defect Formation. J. Mol. Biol. 2004, 343, 1243-1254. [CrossRef] [PubMed]

118. Warzecha, M.; Verma, L.; Johnston, B.F.; Palmer, J.C.; Florence, A.J.; Vekilov, P.G. Olanzapine crystal symmetry originates in preformed centrosymmetric solute dimers. Nat. Chem. 2020, 12, 914-920. [CrossRef] [PubMed]

119. Lovette, M.A.; Doherty, M.F. Multisite models to determine the distribution of kink sites adjacent to low-energy edges. Phys. Rev. E 2012, 85, 021604. [CrossRef]

120. Warzecha, M.; Safari, M.S.; Florence, A.J.; Vekilov, P.G. Mesoscopic Solute-Rich Clusters in Olanzapine Solutions. Cryst. Growth Des. 2017, 17, 6668-6676. [CrossRef]

121. Erdemir, D.; Chattopadhyay, S.; Guo, L.; Ilavsky, J.; Amenitsch, H.; Segre, C.U.; Myerson, A.S. Relationship between selfassociation of glycine molecules in supersaturated solutions and solid state outcome. Phys. Rev. Lett. 2007, 99, 115702. [CrossRef] [PubMed]

122. Parveen, S.; Davey, R.J.; Dent, G.; Pritchard, R.G. Linking solution chemistry to crystal nucleation: The case of tetrolic acid. Chem. Commun. 2005, 1531-1533. [CrossRef] 